\title{
Aplikasi Strategi Pembelajaran dan Pengaruhnya Terhadap Prestasi Belajar Peserta Didik
}

\author{
Subaedah \\ Dosen Tetap Universitas Muslim Indonnesia \\ subaedah.subaedah@umi.ac.id
}

\begin{abstract}
Abstrak
Tujuan penelitian adalah: (1) untuk mengetahui strategi pembelajaran yang diterapkan di MAN 03 Daya Makassar, (2) untuk mengetahui prestasi belajar siswa, (3) untuk mengetahui pengaruh strategi pembelajaran terhadap prestasi belajar siswa. Jenis penelitian ini adalah ex post facto bertujuan untuk mengetahui dan melihat pengaruh yang ditimbulkan dalam aplikasi strategi pembelajaran terhadap prestasi belajar siswa. Peneliti tidak melakukan kontrol terhadap variabel karena manifestasinya sudah terjadi, atau dapat dikatakan bahwa variabel-variabel dalam penelitian tidak dapat dimanipulasi. Pengambilan data awal lewat observasi dan survey, variabel terikat ditentukan lebih dulu serta uji validasi lewat triangulasi. Instrumen penelitian: obeservasi, wawancara, angket dan dokumetasi. Analisis data menggunakan kriteria yang diindikatorkan menerima dan menolak $\mathrm{H}_{0}$ Hasil penelitian dengan apabila $t$ hitung lebih kecil atau sama dengan $t$ tabel maka $\mathrm{H}_{0}$ diterima ( $t_{\mathrm{hit}} \leq t_{\mathrm{tbl}}=\mathrm{H}_{0}$ diterima ) pada taraf signifikansi $\alpha=0.05$ dan derajad bebas $(\mathrm{db})=n_{1}+n_{2}-2$. Hasil penelitian menunjukan pretest kemampuan siswa pada K.E dan K.K hampir sama. Perbedaan ada pada nilai rerata kelas dan nilai maksimum sebesar 0.06. . Nilai rerata pretest pada kelas eksperimen sebesar 9.50 dan pada kelas kontrol sebesar 9.44. Nilai maksimum pada kelas eksperimen sebesar 14 sedangkan pada kelas kontrol sebesar 15. Perbedaan hanya sebesar 1 angka. Adapun nilai yang sama adalah nilai median sebesar 10, nilai mode sebesar 10, dan nilai minimum sebesar 6 . Pada postest terjadi perbedaan rerata, median, mode, minimum, dan maksimum pada kelas eksperimen dan kelas kontrol. Pada kelas eksperimen rerata postest sebesar 16.55 sedangkan pada kelas kontrol sebesar 19.04. Perbedaan rerata sebesar 2.49. Nilai median kelas eksperimen sebesar 17 sedangkan pada kelas eksperimen sebesar 20. Perbedaaan mediannya sebesar 3 angka. Nilai mode pada kelas eksperimen sebesar 18 sedangkan pada kelas kontrol sebesar 20. Perbedaan modenya sebesar 2 angka. Nilai minimum pada kelas eksperimen sebesar 11 sedangkan pada kelas kontrol sebesar 13. Perbedaan nilai minimumnya sebesar 2 angka. Nilai maksimum pada kelas eksperimen sebesar 22 sedangkan pada kelas kontrol sebesar 23. Perbedaan nilai maksimumnya sebesar 1 angka.
\end{abstract}

Kata Kunci: Aplikasi; Strategi Pembelajaran; Pengaruh;, Prestasi Belajar

\section{Pendahuluan}

Dunia pendidikan diharapkan memiliki kualitas pembelajaran yang maksimal, menjadi pusat bagi para praktisi, akademisi, dan pemerhati pendidikan. Fenomena menunjukkan bahwa outcome atau luaran pendidikan formal memiliki berbagai kelemahan, contoh kecerdasan peserta didik hanya dari segi kognitif (pikiran), tidak dibarengi kecerdasan aspek afektif (sikap), dan psikomotorik (keterampilan). Sebaliknya kecerdasan afektif tidak didukung oleh kecerdasan kognitif dan kecerdasan psikomotorik. Begitu juga kecerdasan psikomotorik tidak bersinergi dengan kecerdasan kognitif dan kecerdasan afekti, sehingga peningkatan kualitas proses pembelajaran tersentuh pada semua aspek yang menjadi ranah dalam pendidikan. ${ }^{1}$

${ }^{1}$ Dalam Undang-undang Sistem Pendidikan Nasional Nomor 20 tahun 2003 merupakan respon terhadap akumulasi dari fenomena dan tuntutan zaman mengenai pendidikan nasional. Bagaimana pendidikan dapat menjawab problematika hidup harus didukung oleh landasan yuridis, sebagai kekuatan formil pelaksanaan pendidikan di Indonesia. 
Kualitas pendidikan yang semakin menurun, menjadikan pendidik harus lebih meningkatkan profesionalismenya dalam kompetensi pedagogik dan kompetensi-kompetensi yang lain, sehingga mampu mengikuti dinamika dan perkembangan teknologi mutakhir. Pendidik bukan hanya dituntut dalam penguasaan materi pembelajaran akan tetapi juga dalam kemampuan penyajian materi pada peserta didik. ${ }^{2}$ Beberapa teknik pembelajaran yang dapat dijadikan penggerak efektivitas strategi pembelajaran dan memungkinkan terjadinya interaksi edukatif (Pendidikan) dalam kelas. Permasalahan dalam penelitian ini adalah bagaimana strategi pembelajaran, bagaimana prestasi belajar, dan bagaimana pengaruh strategi pembelajaran terhadap prestasi belajar.

\section{Metode Penelitian}

\subsection{Jenis dan Pendekatan Penelitian}

Jenis penelitian adalah ex post facto yang bertujuan untuk menemukan penyebab yang memungkinkan perubahan prilaku. Secara metodis penelitian ex post facto merupakan penelitian eksperimen yang menguji hipotesis tanpa memberikan perlakuan tertentu. Karakteristik penelitiasn ex post facto: a) pengumpulan setelah peristiwa terjadi, b) penentuan variabel terikat, c) penelitian deskriptif, d) ada korelasi: menemukan hubungan kausal fenomena yang diteliti.

\section{Teknik analisis data}

Teknik analisis data yang digunakan untuk mengetahui apakah ada pengaruh signifikan strategi pembelajaran terhadap prestasi belajar siswa dengan menggunakan uji $t$. Kriteria yang digunakan dalam menerima dan menolak $\mathrm{H}_{0}$ sesuai dengan pendapat Sugiyono (2016: 276) bahwa: apabila $t$ hitung lebih kecil atau sama dengan $t$ tabel maka $\mathrm{H}_{0}$ diterima $\left(t_{\mathrm{hit}} \leq t_{\mathrm{tbl}}=\mathrm{H}_{0}\right.$ diterima $)$ pada taraf signifikansi $\alpha=0.05$ dan derajat bebas $(\mathrm{db})=n_{1}+n_{2}-2$. Sebelum dilakukan uji $t$ lebih dulu dilakukan serangkaian uji persyaratan yang harus memenuhi asumsi tertentu. Asumsi tertentu itu adalah merupakan data yang berdistribusi normal, rerata varian bersifat homogen. Sebelum uji $t$ terlebih dulu dilakukan pengujian normalitas dan homogenitas.

\section{Hasil Penelitian}

\subsection{Strategi pembelajaran di MAN 03 Daya}

Umumnya strategi pembelajaran terdiri atas dua yaitu exposition-discovery learning dan group-individual learning, deduktif, dan induktif. Strategi pembelajaran exposition merupakan strategi pembelajaran yang materi ajar diberikan kepa peserta didik dalam bentuk jadi, dan peserta didik dituntut menguasai materi ajar. Pembelajaran ini disebut pembelajaran langsung. Strategi pembelajaran deduktif merupakan strategi pembelajaran yang dilaksanakan dengan mempelajari konsep kemudian menarik satu kesimpulan, materi pelajaran bermula dari yang abstrak menuju ke yang konkrit. Sedangkan strategi pembelajaran induktif merupakan bahan materi yang dimulai dipelajari dimulai dari hal-hal konkritdari hal yang nyata (kongkrit) kemudian peserta didik dihadapkan pada materi-materi yang kompleks.

\subsection{Data Tes Pemahaman Konsep IPA}

a. Hasil Tes Belajar IPA Siswa Kelas Eksperimen

1) Deskripsi Hasil Tes Sebelum Eksperimen (Pretest)

Hasil deskripsi pretest kelas eksperimen disajikan pada tabel 1 dibawah ini, skor rata-rata pretest Kelas VB sebesar 9.50, median 10.00, standar deviasi 2.22 dengan nilai minimum 6 dan nilai maksimum 14. Skor rerata prestasi belajar IPA lebih kecil daripada skor median..

\footnotetext{
${ }^{2}$ Lebih jelasnya lihat Soetjipto \& Raflis Kosasi, Profesi Keguruan, (Jakarta: Rineka Cipta, 2007), h.
} 51. 
Tabel 1: Deskripsi Pretest Siswa K.E (Kelas VB)

\begin{tabular}{|l|r|}
\hline N $\quad$ Valid & 22 \\
Mean & 0 \\
& 9.5000 \\
Mode & 10.0000 \\
Std. Deviation & 10.00 \\
Minimum & 2.22004 \\
Maximum & 6.00 \\
Sum & 14.00 \\
\hline
\end{tabular}

Hasil pretest menunjukkan belumada peserta didik memenuhi standar skor 16 dari skor maksimal 25 dengan standar ketuntasan 63\%.

2) Deskripsi Hasil Tes Setelah Eksperimen (Postest)

Deskripsi hasil postest kelas eksperimen disajikan pada Tabel 6. Tampak pada tabel tersebut skor rata-rata postest Kelas VB sebesar 16.55, median 17.00, standar deviasi 2.807, nilai minimum 11 dan nilai maksimum 22. Skor rata-rata postest IPA lebih kecil daripada skor median. Hal ini berarti bahwa lebih dari 50\% siswa kelas kelas eksperimen memiliki skor postest diatas skor ratarata.

Tabel 2: Deskripsi Postest Siswa K.E (Kelas VB)

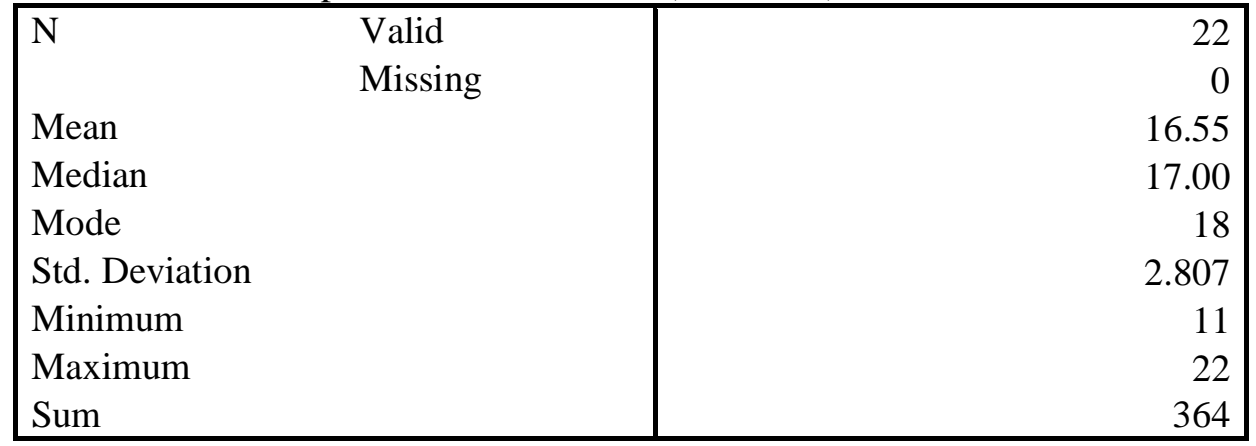

rerata peserta didik memenuhi standar ketuntasan dengan standar skor 16 atau standar ketuntasan minimalnya $63 \%$. Peserta didik yang tuntas pada K.E berjumlah 15 orang atau sebesar $68.2 \%$ dari 22 orang peserta didik. Peserta didik yang belum tuntas sebanyak 7 orang atau $31.8 \%$.

b. Hasil Tes Belajar IPA Kelas Kontrol

1) Deskripsi Hasil Tes Sebelum Perlakuan (Pretest)

Skor rata-rata postest Kelas VA sebesar 9.44, median 10.00, standar deviasi 2.123, nilai minimum 6 dan nilai maksimum 15. Skor rata-rata prestasi belajar IPA lebih kecil daripada skor median. Hal ini berarti bahwa lebih dari $50 \%$ peserta didik K.K memiliki skor postest diatas skor rata-rata.

Tabel 3: Deskripsi Pretest Siswa K.K (Kelas VA)

\begin{tabular}{|c|c|c|}
\hline $\begin{array}{l}\mathrm{N} \\
\mathrm{Me} \\
\mathrm{Me} \\
\mathrm{Mc} \\
\mathrm{Std} \\
\mathrm{Mi} \\
\mathrm{Ma} \\
\mathrm{Su}\end{array}$ & $\begin{array}{l}\text { Valid } \\
\text { Missing }\end{array}$ & $\begin{array}{r}25 \\
0 \\
9.44 \\
10.00 \\
10 \\
2.123 \\
6 \\
15 \\
236\end{array}$ \\
\hline
\end{tabular}


Hasil pretest melebihi nilai rerata kelas. Dari hasil pretest belum ada peserta didik yang memenuhi standar skor 16 dari skor maksimal 25 dengan standar ketuntasan 63\% sebab skor tertinggi perolehan peserta didik kelas kontrol adalah 15.

\section{2) Deskripsi Hasil Tes Setelah Perlakuan (Postest)}

Deskripsi hasil postest kelas kontrol pada tabel 4 tersebut skor rata-rata postest Kelas VB sebesar 19.04, median 20.00, standar deviasi 2.700, nilai minimum 13 dan nilai maksimum 23. Skor rata-rata prestasi belajar IPA lebih kecil daripada skor median. Hal ini berarti bahwa lebih dari $50 \%$ peserta didik K.E memiliki skor postest diatas skor rata-rata.

Tabel 4: Deskripsi Postest Peserta Didik K.K (Kelas VA)

\begin{tabular}{|l|c|}
\hline N $\quad$ Valid & 25 \\
$\quad$ Missing & 0 \\
Mean & 19.04 \\
Median & 20.00 \\
Mode & 20 \\
Std. Deviation & 2.700 \\
Minimum & 13 \\
Maximum & 23 \\
Sum & 476 \\
\hline
\end{tabular}

Rerata peserta didik telah memenuhi standar ketuntasan minimala 63\%. Pada Peserta didik K.K persen peserta didik yang tuntas sebanyak $88 \%$ atau sebanyak 22 dari 25 orang peserta didik, yang belum tuntas sebanyak $12 \%$ atau sebanyak 3 peserta didik dari 25 orang peserta didik.

Data hasil tes pemahaman konsep di atas dapat dirangkum perbandingan deskripsi K.E dan K.K yang terlihat pada Tabel 5 berikut:

Tabel 5: Perbandingan Hasil Pretest dan Postest K.E dan K.K

\begin{tabular}{|l|c|c|c|c|}
\hline \multirow{2}{*}{ Aspek } & \multicolumn{2}{|c|}{ Kelas Eksperimen } & \multicolumn{2}{c|}{ Kelas Kontrol } \\
\cline { 2 - 5 } & Pretest & Postest & Pretest & Postest \\
\hline Rerata & 9.50 & 16.55 & 9.44 & 19.04 \\
\hline Median & 10 & 17 & 10 & 20 \\
\hline Mode & 10 & 18 & 10 & 20 \\
\hline Minimum & 6 & 11 & 6 & 13 \\
\hline Maksimum & 14 & 22 & 15 & 23 \\
\hline
\end{tabular}

Tabel 5 menunjukan bahwa pada saat pretest kemampuan peserta didik pada K.E dan K.K hampir sama. Perbedaan dapat diamati adalah pada nilai rerata kelas dan nilai maksimum. Nilai rerata pretest pada K.E sebesar 9.50 dan pada K.K sebesar 9.44. Perbedaan hanya sebesar 0.06. Nilai maksimum pada K.E sebesar 14 sedangkan pada K.K sebesar 15. Adapun nilai sama di nilai median sebesar 10, nilai mode sebesar 10, dan nilai minimum sebesar 6. \% ketuntasan K.E sebesar $68.2 \%$ dan tidak tuntas $31.8 \%$, sedangkan K.K $88 \%$ tuntas dan tidak tuntas $12 \%$.

1. Data Minat Peserta Didik terhadap Pembelajaran IPA

Kategori minat peserta didik yang digunakan dalam penelitian ini terbagi kedalam empat kelompok, yakni kelompok minat sangat tinggi, tinggi, rendah, dan sangat rendah. Kategori minat peserta didik bergantung pada skor angket yang diperoleh. Adapun Deskripsi hasil pengukuran minat peserta didik K.E dan K.K pada Tabel 6 berikut: 
Tabel 6: Deskripsi Minat Peserta Didik K. E dan K.K

\begin{tabular}{|c|c|c|c|c|}
\hline \multirow{2}{*}{ Aspek } & \multicolumn{2}{|c|}{ Kelas Eksperimen } & \multicolumn{2}{c|}{ Kelas Kontrol } \\
\cline { 2 - 5 } & $\begin{array}{c}\text { Sebelum } \\
\text { Perlakuan }\end{array}$ & $\begin{array}{c}\text { Setelah } \\
\text { Perlakuan }\end{array}$ & $\begin{array}{c}\text { Sebelum } \\
\text { Perlakuan }\end{array}$ & $\begin{array}{c}\text { Setelah } \\
\text { Perlakuan }\end{array}$ \\
\hline $\mathrm{N}$ & 22 & 22 & 24 & 24 \\
\hline Mean & 52.23 & 52.86 & 46.38 & 50.04 \\
\hline Median & 55.00 & 53.00 & 46.00 & 48.50 \\
\hline Mode & 56 & 53 & 44 & 45 \\
\hline Minimum & 37 & 44 & 38 & 40 \\
\hline Maksimum & 69 & 63 & 61 & 63 \\
\hline
\end{tabular}

Tabel 6 memperlihatkan jumlah sampel (N) dari kedua kelompok berbeda, K.E sebanyak 22 peserta didik dan K.K sebanyak 24 orang. Jumlah peserta didik K.K sebenarnya adalah 25 orang namun pada saat postest salah seorang diantaranya tidak hadir. Mean merupakan rata-rata skor yang diperoleh peserta didik setelah dijumlahkan dan dibagi dengan banyaknya peserta didik.

\section{Simpulan}

Berdasarkan hasil penelitian dan pembahasan yang telah dikemukakan pada bab sebelumnya, dapat disimpulkan sebagai berikut:

a. Srategi pembelajaran di MAN 03 Daya Makassar menggunakan beberpa strategi pembelajaran salah satunya dengan menggunakan metode learning discovery

b. Prestasi belajara siswa yang meningkat dengan nilai rerata eksperimen $\bar{X}=16.55<$ metode demonstrasi $\bar{X}=19.04$ ).

c. Terdapat pengaruh strategi pembelajaran terhadap hasil belajar siswa yang signifikan antara siswa kelas eksperimen dan kelas kontrol setelah diberi perlakuan $(p=0.004<\alpha=0.05)$. Pemahaman konsep IPA siswa yang diajarkan melalui strategi pembelajaran discovery lewat metode eksperimen $\bar{X}=16.55<$ metode demonstrasi $\bar{X}=19.04$ ). 


\section{DAFTAR PUSTAKA}

Abdullah, Abu Muhammad Ibnu, Prestasi Belajar, dalam http://spesialis-torch.com/ diakses tanggal 22 April 2014.

Ahmadi, Abu dan Joko Triprasetyo, Stategi Belajar Mengajar, Cet. I; Bandung: Pustaka Setia, 2015.

Arikunto, Suharsimi, Prosedur Penelitian, Cet. XXI; Jakarta: PT. Rineka Cipta, 2015.

Ary, Donal., Luchu Cheser Jacobs, dan Asghar Rasavieh. Pengantar Penelitian dalam Pendidikan terj. H. Arief Furchan, Cet. I; Yogyakarta: Pustaka Pelajar, 2013.

Denzin, Norman K., \& Yvonna S.Lincoln (Eds.), Handbook of Qualitative Research, terj. Dariyatno, Badrus Samsul Fata, dan Jhon Rinaldi, Handbook of Qualitative research, Yogyakarta: Pustaka Pelajar, 2012.

Dimyati dan Mudjono, Belajar dan Pembelajaran, Departemen Pendidikan dan Kebudayaan, 2016.

Djamarah, Saiful Bahri, Psikologi Belajar, Cet. I; Jakarta: Rineka Cipta, 2012. , dan Aswan Zain, Strategi Belajar Mengajar, (Cet.VI; Jakarta: PT. Rineka Cipta, 2016

Efendi, Agus, Revolusi Kecerdasan Abad 21: Kritik MI, EI, SQ, AQ, \& Successful Intelligence atas IQ, Bandung: Alfabeta, 20

Gintings, Abdorrakhman Esensi Praktis Belajar dan Pembelajaran: Disiapkan untuk Pendidikan Profesi dan Sertifikasi Guru-Dosen, Cet. II; Bandung: Humaniora, 2015.

Hadi, Sutrisno, Statistik, Jilid VII; Yogyakarta: Andi Offset, 2015.

Malik, Ny. R. dkk., Jenis Alat Peraga/Alat Permainan dan Teknik Penggunaanya, Jakarta: Penerbit Kasturi, 1986.

Margono, S., Metodologi Penelitian Kualitatif, Cet. IV; Jakarta: Rineka Cipta, 2014.

Mastuhu. Memberdayakan Sistem Pendidikan Islam. cet. V; Jakarta: Logos, 2015.

Muhadjir, Noeng, Metodologi Penelitian Kualitatif, Yogyakarta: Rekersarasin, 2015.

Muhaimin. Rekontruksi Pendidikan Islam: Dari Paradigma Pengembangan, Manajemen Kelembagaan, Kurikulum hingga Strategi Pembelajaran. Jakarta: Rajawali Pers, 2009.

--------, et al., Paradigma Pendidikan Islam: Upaya Mengefektifkan Pendidikan Agama Islam di Sekolah. Bandung: Remaja Rosdakarya, 2011.

Peraturan Pemerintah Nomor 19 Tahun 2005, tentang Standar Nasional Pendidikan, Bab IV, Pasal 19

Poerwanto, M. Ngalim., Psikologi Pendidikan, Cet. V, Jakarta: Remaja Rosda Karya, 2015

Rahman, Abd., Pengelolaan Pengajaran, Cet. III; Ujung pandang: Bintang selatan, 2015. 